\title{
A Context-Grounded Approach to Religious Freedom: The Case of Orthodoxy in the Moldovan Republic
}

\author{
Davide N. Carnevale \\ Human Rights Centre, University of Padova, Via Martiri della Libertà, 2, 35137 Padova, Italy; \\ davidenicola.carnevale@phd.unipd.it
}

Received: 30 March 2019; Accepted: 3 May 2019; Published: 9 May 2019

\begin{abstract}
This paper explores the relationship between human rights and social analysis within the main historical and theoretical perspectives adopted by social sciences. In particular, religious freedom will be analysed as one of the central issues in the recent engagement of the social sciences with human rights. After examining current narratives and mainstream approaches of the social sciences towards the right to religious freedom, this article will then underline the importance of a social epistemology which goes beyond a normative and legal perspective, bridging the gap between the framework of human rights and the social roles of religion in context. Within this framework, religious freedom represents a social construct, whose perception, definition and implementation dynamically evolves according to its influence, at different levels, in the lived dimension of social relations. The second part of the article proposes a context-grounded analysis of religious freedom in the Republic of Moldova. This case study is characterised by the impressive growth of Orthodoxy after the demise of the Soviet Union and by a complex and contradictory political approach towards religious freedom, both as a legal standard and as a concept. Emerging through the analysis of local political narratives and some preliminary ethnographical observations, the social importance of religion will be investigated both as a governmental instrument and as an embodied means of dealing with widespread socio-economic insecurity, creating tensions between religious rootedness and religious freedom. The local debate on religious freedom will then be related to the influence of geopolitical borders, the topic of traditional identity and the religious form of adaptation to the ineffectiveness of the new secular local policies, with orthodox institutions and parishes having new socio-political roles at both a global and local scale.
\end{abstract}

Keywords: religious freedom; Republic of Moldova; Eastern Orthodox Christianity; religion and human rights; gaps in normative perspectives; socio-anthropology of human rights; religion and politics

\section{Human Rights and Social Analysis. Going Beyond a Normative Perspective}

The relationship between religion and politics, abundantly evident nowadays, has until recently been treated as an 'ethnological' argument in both public and academic debate. It was considered a residual phenomenon, according to a postulated global, homogenous and progressive process of modernisation, westernization and rationalisation of social behaviours. It is no coincidence that, at first glance, these three terms might appear to be almost synonymous. Heir of the political history of Western institutions, and grounded in a legal and philosophical discourse mostly influenced by the liberal tradition, the conceptualisation of human rights shared this normative cultural assessment, which has usually been distanced from the social, political and economic history associated with its concrete creation and evolution. Selecting, ratifying, adopting and universalising the legal entitlements claimed during a century of civic and social struggles, the Universal Declaration of Human Rights (UDHR) was seeking to indicate the path towards building a common ethical regime founded on the (same) innate values and dignity of every human being in all human societies. This new regime therefore, would 
be able to protect individuals, prevent and repair claims of illegitimate power within national and international relations, in support of a rational organisation of societies and their adherence to universal ethical principles. Albeit gradually, after 1948, we observed the creation and growing institutionalisation of a human rights discourse, based on the abovementioned presuppositions and formed by a corpus of documents, publications and legal intervention. Around the normative definition of this body of laws, there emerged a scattering of different governmental and nongovernmental organisations and included the involvement of intellectuals, activists and social actors, sharing discourses, practices and social networks in multiple locations.

As suggested by Goodale (2009), a considerable acceleration of these phenomena took place after the end of the Cold War. The fall of the Iron Curtain represented the key event of a new wave of transnationalisation in the human rights discourse, confirming human rights as a unified normative frame and as a pervasive and authoritative driver of civilisation. Among human rights advocates, this supposed 'end of the history' (Fukuyama 1992) seemed to provide a real possibility of constituting a more unified legal system, a new global order which would have given the human right discourse the capacity of altering practices in governance, endorsing good practices and ending inhuman violations. The concrete diffusion of this model on a worldwide political scale, mainly backed by international law, came along with a growing economic intertwining (Barnett and Finnemore 2004; Nash 2015). The expansion of neoliberal economies, and of globalisation in more general terms, forced the general attitude of human rights to face, even in its internal debate, the growing variance in theory and practices produced by the local implementation of these same legal standards. As stated by Palombella (2006), among others, the discrepancy between the different collective cultures operating in an interconnected social and institutional system could not be addressed by the pure homogeneous normativity of rights but required the negotiation of an equilibrium between this legal system and the recognition of the different social practices of groups. The effort to preserve the worldwide applicability and effectiveness of human rights principles, addressing at the same time the diversity of socio-political and cultural contexts, could also have significant consequences in rethinking the further development of human rights theory and practices. Firstly, it brings under discussion individualism in human rights concepts, moving towards the intersubjective character of rights. Secondly, it can guide the human rights institutional discourse towards a debate of its political contradiction in interventions and purposes. Furthermore, it suggests inverting the direction from which legitimacy flows, creating a more attentive empirical framework and a less advocacy-oriented approach towards local contexts. Finally, it represents a fundamental push-factor in going beyond the legal perspective and involving social scientists in an inter-disciplinary challenge, in line with this attempt to give to the human rights discourse the cross-cultural flexibility and epistemological sensibility needed by the paradigm of 'tolerable tension' of rights, and also, by a scientific understanding of rights in themselves.

Bridging human rights and social sciences can be particularly important in approaching the topic of freedom of religion. It is a topic that, as Georg Jellinek already underlined, is at the historical origin of the human rights discourse; despite this, it has long been influenced by a philosophical post-Enlightenment posture which, especially in the European tradition, contemporaneously relied upon a secular deliverance from suffering and a direct incompatibility between religious consciousness and political recognition and emancipation. The observation of the plurality of roles the religious dimension has in connection with social and political phenomena offers a better understanding of both religions and rights. It imposes a fundamental challenge, one which was inaccessible to answer through an essentialist interpretation of the secular principle of laicité, and more in general through a normative approach. Distanced from their transcendental traditional ground for legitimacy, both human rights and religions, as well as the issues which deal with the relations between the two, are relevant subjects for social study because they are grounded in the concrete, being part of the political system and taking part in contemporary beliefs and social practices.

In the section that follows we will mention some fundamental topics advanced by the social sciences which could open the debate on the human rights discourse. Then, we will describe possible 
new forms of proximity between human rights discourse and the social sciences on religious freedom. We will look briefly through which approaches and perspectives social scientists are embarking on in the academic study of human rights, a field in which they have been marginal for a long time. We will finally propose a hitherto under-practised approach, which is a context-grounded analysis of human rights, as a key to surpass a naïve and dogmatic relation between human rights and social studies. An anthropological exploration of human rights as a local construct can expose the research to a fruitful middle dialectical space, positioned between a doctrine based on the existence of supposed universal and inalienable rights, with their definition within an apparatus of legal standards and sacred principles, and the political and social realities in which rights are grounded and reconceptualised. An epistemology centred on the contextual analysis of religious freedom will be thus proposed as a valuable approach to bridge the gap between the human rights framework and the social roles of religions.

\section{Toward a Socio-Anthropology of Human Rights. Approaching the Problem of Religious Freedom}

Based on the empirical analysis of societal functioning, involved in cross-cultural documentation of the historicity and diversity in moral systems, sociology and anthropology have long approached the topics of social rules and systems of beliefs as disciplines. Despite this, the direct study of human rights has for a long time been at least a marginal (if not overlooked) field of studies, characterised by a dominant position of silent distance and agnosticism, but also of conscious disengagement. The universality of human rights, a longstanding dogma in legitimating the human rights discourse, hardly fits with the path already inaugurated, albeit in different forms, by Marx, Durkheim and Weber (Madsen and Verschraegen 2013). On the contrary, their epistemological assumptions suggest the inquiry of rights as socially constructed, a result of the institutions, the political bodies and the societal structures in which they are embedded.

Notwithstanding their supposed trans-historicity, human rights can be observed as mechanisms for protecting the functioning and the 'institutionalised expectations' of a modern differentiated society (Luhmann 1965). Their normative definition, even if justified on the basis of philosophical statements on the nature of abstract individuals, is de facto embedded in a specific model of liberal society and citizenship. Secondly, the meaning and the social value of rights cannot be unrelated to the cultural specificity of contexts; the meaning and the recourse to this language change according to the public sphere in which this language is adopted, and on which it is applied. The American Anthropological Association (AAA) already stated this in 1947 in its eponymous anthropological document on human rights, strongly influenced by the Boasian rejections toward evolutionism and cultural universals. Written by Herskovits under the solicitation of UNESCO, this document played no role in the drafting of the UDHR by the well-known Commission chaired by the 'First Lady of the World', Eleanor Roosevelt, after the end of the Second World War (Morsink 1999; Goodale 2009). In the Statement on Human Rights, we read that "what is held to be a human right in one society may be regarded as anti-social by another people, or by the same people in a different period of their history" (AAA 1947, p. 542). In this defence of cultural diversity Herskovits was extremely cautious regarding the risk of ethnocentrism-a "kind of caricature of universalism", Todorov would have said later (Todorov 1992, p. 19). He was also ironically making reference to historical precedents, perceiving in this ambitious project a moral orientation similar to that of the slave-owners who wrote such a "noble [ ... ] document as the American Declaration of Independence, or the American Bill of Rights" (AAA 1947, p. 542). When human rights were still only standing as moral concepts and generic generative principles, he was thus indicating the importance of also taking heed of social institutions and political practices associated with them. As regards the American Sociological Association (ASA), following the genealogical reconstruction of the sociology of rights produced by Somers and Roberts (2008), it did not publish any official document in support of human rights until 2005. The statements mentioned above briefly summarise some of the reasons in the general positioning toward human rights, confirming the opinion, supported by many 
other scholars, that "a sociology of rights still cannot be said to exist" (Somers and Roberts 2008, p. 386). On the other hand, an increasing interest in these issues can be observed, especially from the last decade of the 20th century. Many mainstream academic environments have recently favoured several efforts in this direction, which leads us to believe that "many of the ideas and elements necessary for one have begun to appear" (ibid., p. 386). Both material and conceptual reasons made human rights a challenge and an opportunity social scientists could no longer ignore. The growth of a transnational multi-level governance system from the 1990s onwards, as we have already mentioned, created a new institutional scenario. As a result, also the human rights discourse changed its functions and functioning, broadened roles and field of application, opened new opportunities for researchers and social actors at the global and local level. This wider context in the application of the human rights discourse is radically different if compared to that of seventy years ago, and has more substantial affinities with the involvement and development of the 'applied' or 'public' social sciences. A second, more epistemological, reason of proximity is due to a gradual changing of the moral philosophy inherent to human rights, starting from the concept of human dignity. As was pointed out in the introduction to this paper, the most relevant transformation in the human rights discourse is the growing reference to the social dimension of rights, with the consequence, for example, of a broader recognition of identity and cultural issues. The effects of this transformation are thus detectable not only in the institutional dimension of human rights but also in its internal rhetoric. In human rights studies moreover, the opinion that rights did not originate in the virtuality of a prior individual state of nature is nowadays more common. Increasingly consolidated is rather the centrality of mutual recognition in social relations and the opinion that rights, following the lesson by Habermas (1996), exist while affecting reality, insofar that they undertake to regulate social life. A third empirical reason lies within the growth of the relevance of the language of human rights in the current geopolitical arena and in the organisation of social life. Human rights are an important issue in the scientific study of society because they impact on it. Primarily, they act as an integral part of the transnational institutional architecture, within which the human rights discourse enters into a hegemonic apparatus of knowledge and a regime of legal standards and political interventions. Secondly, human rights language is today almost globally adopted, or at least debated, in different contexts and with different attitudes. Human rights documents are cited by many-also religious-institutions throughout the world, which are challenged or empowered by their moral and political impact in the g-local public sphere. Finally, human rights should also be studied because they are advocated by many local social actors as a widely accepted mode of expressing human needs and claims of injustice in power relations.

Within the new framework we described, the relationship between human rights and religion, mostly expressed through the multifaceted topic of religious freedom, attracts an ever-increasing interest. As mentioned in the previous paragraph, in recent decades the research on religious freedom has becomea growing subfield of the emerging sociology of human rights (Breskaya et al. 2018). Among many types of research, we could mention those involved in broad theoretical discussions on the relationship between religions and human rights traditions (Ferrari 2005; Witte and Green 2012; Joas 2013; de Sousa Santos 2015; Ventura 2015), studies on the intersectionality of the right to freedom of religion with other human rights (Afkhami 2000; Thornberry 2002; Langlaude 2007; Jenkins 2008), researches in the sociology of law and political science regarding religious policies implemented by states (Van der Vyver and Witte 1996; Sarkissian 2015; Grim and Finke 2006), case studies on religious pluralism, on religious education, and on the influence of religious factors and cultural diversities affecting law and regulations (Price 2002; Richardson 2004; Fox 2008), reflections on the central position of the topic of religious freedom within contemporary societies or in global politics (Banchoff and Wuthnow 2011; Finke 2013; Zuber 2017). The literature mentioned above gives the idea of an extremely heterogeneous and multidisciplinary field of study, which gradually is welcoming elements ranging from legal theory to international relations. The result is that of a gradual thematic expansion of the right to freedom of religion, which is thus more closely connected to the various political, historical, and cultural aspects of social life. 
If we were to distinguish common elements of this shift, we could report a prevailing attitude toward the institutional definition of human rights, which is assumed as the starting point of many of these researches. The process of definition of this new field of research partly inverted the traditional sociological approach, from society to rights, inaugurating a field in which rights represent the direct setting for any further societal observation. This new engagement with human rights usually does not question their foundation, and social researchers mainly work within the normative framework, through the standard conceptual definition of human rights they were also presumed to study. As a consequence, the subfield involved in studying religious freedom also seems oriented towards following the institutional process of definition of international standard-settings. This attitude has significant epistemological consequences, especially for studies that aim to analyse the local social relevance of religions and human rights. Religious issues would be interpreted mostly in terms of compatibility or resilience toward the implementation of human rights standards. Furthermore, empirical researches and case-studies on local contexts and religious traditions will mainly be oriented toward the creation of reference tools and sociological instruments for the task of legal measurements, according to preconceived parameters (Grim and Finke 2006; Van der Ven and Ziebertz 2012). If quantitative studies are mostly concentrated on comparative analyses of human rights performance, as well as in monitoring the social perception of the already pre-conceptualised category of human rights, qualitative researches frequently would rely on 'human rights reports' based on case studies, with a naive negligence of the value of structural, social, cultural and historical specificity of contexts. The first approach reinforces a normative reference to the standard definition of religious freedom, which could, as we have already mentioned, have many problematic outcomes when related to understanding religious freedom in contexts. The lack of ethnographic sensibility in the second approach would enforce a reasonable tendency instead to dismiss individual narratives and qualitative observations as purely anecdotal and advocacy-oriented.

A well-known example of this epistemological approach is that which Brian Turner proposed in 1993. Turner inaugurated indeed a 'theory of human rights' still grounded in the concept of human nature, which was considering as plausible a model of global governance based on values derived from natural law (Turner 1993). If this foundationalist approach, in theory, seems to release the language of human rights from its legal codification, it epitomises at the same time the instrumental logic of the human rights apparatus. A similar attitude may also be shared in the case of a clear engagement of scholars in the promotion of human rights values, organisations and projects. This is the case of Turner (1997), directly involved in incorporating the human rights discourse in 'emancipatory cultural politics', as well as the proposal of an 'engaged anthropology' by Ellen Messer, supporting the intent of developing standards and universal methods which integrate cultural relativism as a "part of human rights teaching" (Messer 1993, p. 235). These well-known proposals responded to the criticism made by Herskovitz by giving the global project of human rights the possibility to expand the definition of human rights within an anthropological perspective, in coherence with the general attitude inaugurated in the 1990s (AAA 1999). At the same time, they confirm the ontological definition as a pivot of human rights, while maintaining the intent to study it; they incorporate the legal discourse with a consequent legitimating of the normative approach on which the technology of human rights bases its interventions.

While not underestimating the relevance of these studies, this article proposes the necessity of moving on a step further, which is still largely underdeveloped. Grounding the analysis of human rights directly in the local narratives, rights can be tackled in their lived and socially constructed dimension, where the never-ending process of conceptualisation and reconceptualisation takes place. The reasons for placing the social life of rights at centre stage, also beyond its normative definition, are straightforward; values and norms need to be analysed as socially centred, as does the right to religious freedom as a culturally situated social praxis. Yet the process of definition in itself-how the narrative of religious freedom is debated by social actors in relation with the context, how its meanings are adapted, influenced and shaped by g-local power relations and by the development of multiple 
and particular societal features-became the direct object of analysis. This constructivist approach, we notice, does not represent new purposes, but is more a prosecution of the classical social approach towards the role of laws, rights, morality and beliefs. The supposed universal and neutral content of human rights, incorporated by laws, became a discourse that can only be observed empirically, and is still not identified as ascertained. Comparing this approach with that of researches which incorporate the ontological definition of religious freedom, we notice some important epistemological outcomes. Firstly, it fosters a conscious attention toward the issue of cultural relativism, which is a fundamental prerequisite for any socio-anthropological understanding of religions, as well as religious freedom, in contexts. An exploration of the social construction of human rights pushes the analysis toward a critical and non-dogmatic use of theoretical interpretative categories, "controlled by the explicit awareness of the historical Western genesis of those categories" (De Martino 1977, p. 393). Secondly, this approach frames the normativity in religious freedom discourses as a result of a performative process of legal institutionalisation, "a social process, involving power, and that it should be analysed and not assumed to be beneficial" (Freeman 2002, p. 85). Consequently, the constructs of religious freedom need to be explored from the bottom. A context-grounded analysis would invert the direction from which the institutionalised human right speech flows; it stimulates observations focused on the dialectical, processual relation between the concrete practices of different social actors with their agency and intersubjective experience, and the international written set of regulations with their structure. No longer only limited to procedural issues or governance monitoring, these studies can move human rights toward the hermeneutical effort to overcome an institutionalist approach and address both laws and religions as processual and dynamic cultural systems, represented by different institutions and actors, and producers of meaningful and plural attitudes, beliefs and social practices.

In the following part of this article, we will attempt to observe the problem of religious freedom by connecting it with the specificity of the regional contextof the Moldovan Republic. We will analyse dynamics in the development and promotion of the right to religious freedom, which attitudes toward the political implementation of this right we can detect among social and political actors, paying particular attention to how and why this topic is debated in this context by Orthodox Churches and religious actors. An initial preliminary activity will thus be to bridge the gap between the socio-political analysis of the Moldovan context with the normative reflection about the freedom of religion previously mentioned. We will finally observe some issues which are inherent to a grounded conceptualisation of religious freedom, following the already mentioned hypothesis that an analysis of religious freedom cannot be but based on the exploration and recognition of the social roles religion actively plays at the global and local level, well before any legal definition can be formulated through the language of rights.

\section{A Post-Soviet Republic, a New Orthodox State. Approaching the Moldovan Case}

The religious scenario of the Republic of Moldova represents an intriguing and privileged field for a socio-anthropological analysis of religious freedom, which clarifies how this investigation cannot avoid taking into account a many-sided, multi-level contextualisation of the social and political role of religions. Mostly overlooked by Western public and scientific debate, the Moldovan region represents a significant example of contemporary political and institutional transfiguration, as well as exemplifying the processes of re-elaboration of social and individual behaviours operating in post-Soviet contexts. Both these interdependent phenomena are characterised by the emerging of Christian Orthodoxy as one of the most influential factors. Some fundamental aspects of the Moldovan social reconfiguration can be observed through the, albeit often silent, debate on religious freedom; this issue emerges for example while dealing with the institutional relations between clergy and political parties, with the new role in governance and welfare held by churches on a regional scale, with the re-adaptation of Orthodox practices, rituals and theology, to the contemporary economic and political paradigms, human rights discourse included. Furthermore, contextualising the role of religion in the Moldovan republic gives us the possibility, within its particularities, to stress a possible affinity between the contemporary scenario, 
characterised by the general crisis of the twentieth century's political patterns, and a phenomenon that in the academic literature of recent decades has assumed different definitions. Definitions like 'God's revenge', re-enchantment, de-secularization, de-privatisation of religion or religious rebirth (Kepel 1992; Casanova 1994; Cox 1994; Berger 1999; Thomas 2005), which from different orientations indicate a reconsideration of the influence of religions in contemporary individual and social actions.

Wedged between Romania and Ukraine, between the Russian sphere of influence and promises of admission to the European Union, Moldova is a small, landlocked territory, for centuries contested between different hegemonic poles and deeply integrated during the second half of the twentieth century in the political structures and the ideological and cultural patterns of the Soviet period. This parliamentary republic occupies indeed the territory of the former RSS Moldovenească, which was one of the six Soviet Socialistic Republics of the European continent. After the declaration of independence, in August 1991, the new ruling class in Chisinau - not much different from the former-was engaged in the construction of a national identity for a region that "has never been a national state" (Dupouy 2001, p. 56). Moldova experienced a troublesome and contradictory institutional and economic transition, primarily directed by the former Soviet nomenclature, then converted in local business networks, by pressures of international economic partners, starting from Russia, and by conditional loans provided by the IMF and European Bank (Negură 2015; Cazacu and Trifon 2017). The organisation of political authority, the allocation of economic resources, and the positioning in the new geopolitical context-three main fields of any State-building project - had to be managed. This was carried out, with problematic outcomes, according to radically new directives: the establishment of a democratic regime with European standards, the conversion to a market economy drastically removed from state direction and protection, and a relocation within a new field of globalised forces. The current extremely fragile economy of the country is still mainly agricultural and very much tied to foreign trade, in accordance with the inter-regional productive planning of the Soviet era. The main industrial and energetic poles of the former RSSM are located on the Eastern border, in the Transdnestr Republic. The existence of this de facto autonomous region, after its unilateral declaration of independence in September 1990, is exemplar of how the nation-building process and the creation of a nationally effective political authority are far from being accomplished (Cojocaru 2006; Dailey et al. 1993). The main socio-political problems of the country remained virtually unchanged or unresolved after almost three decades, among them a dramatic decline in purchasing power and social services, a problematic handling of the Russian influence and of the rapprochement with Romania, a lack of control of the tensions derived from economic distress and ethnic and linguistic diversity. A third of the potential labour force of the country, equivalent to approximately $25 \%$ of the population and the electorate, live and/or work abroad, with Russia followed by Italy as a top destination. Approximately $26 \%$ of the national GDP comes with certainty from the remittances sent by the so-called 'Moldovan guest-workers'. Due also to the huge decrease in industrial and agricultural output following the dissolution of the Soviet Union, immigration became the main reason for the growth of the service sector, which dominates Moldova's formal economy composing over $50 \%$ of the national GDP (NBS 2018).

The analysis of the current situation, here only briefly mentioned, suggests a virtually permanent condition of crisis, whose fundamental component is the structural fragility of the political apparatus in handling the social, economic and geopolitical problems of the country. This fragility is also deeply significant in the effectiveness and reliability of monitoring human rights in the State's agenda. According to the Report for Human Rights Practice by the United States Department of State (2017), the lack of credibility and effectiveness of the government, police and judiciary is indeed also one of the main problems in the implementation of human rights standards. Furthermore, most of the official reports and monitoring activities place only the region of Bessarabia under observation, without any systematic access whatsoever to the separatist region of Transnistria. The left bank of the Dniestr river is still a grey-zone, almost untracked by international organisations (Bobick 2011). The Republic of Moldova is a party to many international human rights documents (ECHR, ICCPR, ICESCR) and other legal obligations that should promote, protect and fulfil fundamental rights in this area, including 
minority rights and freedom of religion. Yet, many of the events that have happened in the last three decades indicate that the recognition of these standards under international law is merely lip service and interpreted as a formal step required to foster the European integration process. For the same reason, regarding the commitment to the human rights agenda, the country is approaching many of these obligations instrumentally and inconsistently, also depending on the change of positioning in the international balances (Suveică and Sprînceană 2015).

In a 2004 census, fifteen years after the end of Soviet antireligious cultural policies, $93 \%$ of participating citizens declared their Orthodox faith, a percentage that would rise to $95 \%$ through the exclusion of the urban Bessarabian municipalities of Chisinau and Balţi. This percentage rose to $96,8 \%$ ten years later (NBS 2014). Orthodox churches are today among the public institutions which enjoy greater trust among the population. In a survey conducted in 2016 for Soros Foundation, asking Moldovan people their opinion about the relationship between State and Church the vast majority of participants (80\%) declared they would accept a certain degree of Church involvement in political affairs (Voicu et al. 2017). Furthermore, according to a survey by the Moldovan Institute for Public Policy (2017), the Church totals $79.6 \%$ of favourable opinions, figures which are far from the distrust shown versus the government, the parliament or the president of the Republic. Orthodox leaders seem thus widely considered to be an alternative and preferred source of legitimate social authority.

The collapse of the Soviet regime is an undoubtedly crucial historical factor, and continues to have consequences in the patterns of State-Church relations. At least two fundamental pieces of historical data need to be emphasised. The first is that 1991 marks the fall of a super-political authority, in which the state and the party had taken the responsibility of a global and integrated planning of social life. Its dissolution means, despite different continuities, a drastic transition to a 'light policy', especially as far as social policies are concerned (Rutland 2013). During the same period when the absence of the state was substituting the previous pattern, based on a direct action and global control of economy and society (religious belief included), we observed in Moldova, similar to most of the former Soviet countries, a huge growth in believers and an impressive reopening of hundreds of churches (Tihonov 2013; Moldovan Orthodox Church 2018). The second aspect is that the dogmatisation of atheistic Marxist theories occupied an essential role in the official Soviet ideology. The Soviet program of a collective liberation from religion influenced religious policies and believers' practices, confining Orthodoxy-a religion mainly expressed through a strong sense of liturgical community (Morini 1996) - to the private sphere. After the collapse of the Soviet Union, the Russian Orthodox Church saw a shift from prosecution, but in a warranted position of monopoly, to empowerment, with a hegemonic position now supported within the new organisation of powers by political parties.

Touched by two spheres of influence, now in competition, the Moldovan Republic has a peculiar Orthodox geography: it hosts two different official national Churches. They are both under the jurisdiction of foreign Orthodox Patriarchates, Moscow and Bucharest, standing together in a condition which, although non-canonical from a theological point of view, mirrors the Moldovan geopolitical position. When the independence of the Republic was declared, part of the Orthodox bishops followed the pan-Romanian enthusiasm and the reorganisation of the country's leadership happening in Chisinau, declaring the secession from the Moscow Patriarchate to which the Metropolis was linked as a diocese for fifty years. This alternative Metropolis, the Bessarabian Orthodox Church (BOC), was soon subordinated to Bucharest, a national Patriarchate established as the Romanian autocephalous Church in 1872 when the region of Bessarabia was part of the Russian Empire. Still in dialogue with the supporters of a rapprochement with the European border, the emergence of the BOC reactivated the long regional history of competition between Bucharest and Moscow, which for its part gave the status of self-governing Church to this diocese in 1994 (Livizeanu 1995; Popescu 2004; Ciorba 2011). After ten years of juridical limbo, an intervention of the European Court of Human Rights (ECHR) in 2002 pushed through the legal recognition of the Orthodox Metropolis of Bessarabia. The intervention supported the legalisation of a condition of 'bipolar monopoly' (among other smaller religious institutions) that represented a good compromise across the political spectrum of the Bessarabian region. Not without 
reason, in recent times these two main Churches have been allied in together affirming the social centrality of Orthodoxy. The collaboration partly prevailed on the internal competition, for example, in recent claims over the religious properties confiscated during the Soviet time, as well as in the criticism toward other 'not national' or 'not canonical' religious faiths.

The Moldovan Constitution recognises the freedom of religion as protected by law and it is officially committed to promoting laicity and religious pluralism. According to Article 31 of the Constitution, religious cults are autonomous and separated from the state, while Law n.125 of 2007 protects freedom of conscience of (registered) religious cults and of their members, at the same time explicitly not allowing them to express or manifest publicly political preferences or commitment in socio-political organisation. On the other hand, even the Moldovan Orthodox Church (MOC), linked to the Patriarchate of Moscow, recently took an official distance from the political realm, prohibiting religious actors from getting directly involved in political affairs. Through observation of concrete practices, the political parties maintained close ties with the Orthodox clergy and supported (even financially) its hegemonic role. Orthodox identity is generally considered extremely important in consolidating Moldovan society, even if at the same time, on other occasions, parties cannot renounce public declarations in support of every form of freedom of conscience, by mentioning in particular, the rhetoric of human rights and the importance of the right to freedom of religion. The last one is indeed well declared at all levels in the Moldovan political arena, not only as a norm but also as a sign of the new era.

Among many other examples in the last thirty years, of note is the strong electoral endorsement the pro-Russian candidate Igor Dodon has received from the MOC, through the voices of Metropolitan Bishop Vladimir and many local bishops. During his electoral campaign, Dodon synthesised his political program in three-points: defence of Moldovan statism, neutrality and identity; strong economy and social justice; Orthodoxy and friendly relations with the Russian Federation. On July 2017, as Moldovan ad interim president, he met 100 priests to discuss the importance of Orthodox Christianity on society, making a donation to the MOC of 8000 books to be used for studying religion in schools. He then some weeks later visited Mount Athos for a prayer for the Moldovan people with his counsellors, and members of the Socialist Party. After the election in 2019, during Lent prior to Easter, he defined Orthodoxy as 'one of the pillars on which the statehood of the Republic of Moldova is based, the treasure left as an inheritance by our ancestors'. He frequently advertises his visits to churches, bishops, monasteries, and declared in a TV interview that during their official meeting, Patriarch Kirill told him that his mandate was willed by God. In the days in which this article has been written, Dodon is advising his presence in the XIII World Congress of Families in Verona, one of the Italian cities which hosts the most prominent presence of Moldovan migrants. The support the Moldovan Orthodox Church has given to Igor Dodon since 2016 is still ongoing, and has been openly criticised by one of his opponents, Maia Sandu, who has for the first time put the question of the political influence of the Orthodox Church under the judgment of the Constitutional Court. In their defence, the bishops declared that they were not carrying out political activism, but that they simply cared about the future of the country. Without concrete juridical results, the main effect of this position has been a stronger positioning by the Orthodox hierarchy. In November 2016, the bishop of Balti defined Sandu a non-Christian woman, voted by the gay population and still not married at the age of 40; in brief, as an expression of the degrading and immoral West European lifestyle.

The cases reported here illustrate how a local understanding of religious freedom has to deal not only with laws, their definition and social perception, but with the history and the social role of religion in the context in a broader sense. As well as in approaching all other local political issues (Balan 2009), an enquiry limited to indexing factors of violation or advancement in legal standards would look clearly omissive. The relevance of contextual social issues appears to be significant even if we look to practices in the legal framework. As stated by Catana (2004), for example, the recognition of the fulfilment of legal conditions for the registration of religious groups does not prevent the Moldovan government from using double standards in practice, manipulating the religious scenario through 
the manipulation of the (supposed neutral) instruments that should guarantee neutrality. Moreover, the strong presence of Orthodoxy in society can explicitly be used as a justification of inequality in legal procedures. For example, the registration of other religious groups or the permission for building places of worship has been refused on the grounds that " $97 \%$ of the population of Moldova is Christian" (Islamic Human Rights Commission 2003). The Islamic League of Moldova, an NGO which is today the only legally recognised local Islamic organisation, was registered in 2011 by the Minister of Justice Alexandru Tănase, from the coalition Alliance for European Integration, after more than ten years of legal and political disputes. On the other hand, the intervention of the ECHR in favour of the BOC was an early example of the growing willingness by the Court to support the religious freedom of minority religious groups through legal interventions (Fokas 2015). Also the U.S. embassy, in more recent times, officially declared it is engaged in collaborating and giving visibility to local representatives of religious minorities (United States Department of State 2017).

The observations briefly mentioned above provided the background to the process of identification between State and Church as a first step in addressing the Moldovan debate on religious freedom, going beyond the rhetorical standardisation of speeches regarding this right. According to Durham (2012), the patterns of correlation in positive or negative identification between governmental and religious institutions are a key indicator of the social role of religion. Some noticeable examples revealed a clear tendency towards a positive identification between governmental actors and Orthodox Churches, with the BOC confirming and at the same time further entangling this pattern. According to the analysis by Sarkissian (2015, pp. 88-127) - who crossed two main variables in her study on religious repression: the level of political competition and the structures of religious division in society-we can describe the Moldovan model of religion-state relation as a 'State repressing most by favouring one religion'. Like the other thirteen post-socialist countries, the close relationship between national identity and a dominant religious group led to state favouritism of the religious majority and to the state repression of religious minorities. In this category, Sarkissian says, the majority religion is not controlled politically, but benefits from government favouritism in exchange for support and legitimacy for the leading political force.

We can cross some other useful variables for measuring the compatibility of political contexts with a patterned implementation of the right to freedom of religion. As detected in recent literature, with particular attention to two of the considered eponymous works on religious freedom (Richardson 2006; Finke 2013) we can mention: the presence of enforcement policies by a strong State; an intimacy with a 'culture of autonomy' among decision-makers in the legal system and political institutions; a combination of religious diversity and 'Westernization' of values; a combination of religious diversity and political competition; a good g-local prestige of the alternative faiths; a legal system and institutional policies not involved in enforcing the privileges of the dominant religions; the presence of efficient power-groups and organizations that support the implementation of religious freedom. Briefly looking at the Moldovan case through these variables, we can observe some significant gaps in convergence. A huge component of local decision-makers does not express cultural intimacy in the matter of laicism, despite the strongly secular past. It has few, marginalised and sometimes ridiculised religious minorities (especially outside the main urban contexts). Its decision-makers often have a selective, both alternative and strategic, reception of the so-called 'Western values', like individual autonomy, religious tolerance, and so on. The country is also characterised by a fragile third-party sector, which faces widespread disillusionment toward civil institutions, and is made even weaker by geopolitical partisanships. As already mentioned, political institutions are explicitly involved in enforcing the central role of Orthodoxy, also beyond the official limit imposed by the legal system. Furthermore, as anticipated earlier, the Moldovan Republic suffers permanent structural weakness. The ambiguity of political speeches about human rights is generally perceived from the point of view of international organizations (UN Human Rights Council 2012) as the sign of a fledging-but in progress-transition toward a new political model. It seems instead to be the sign of a consolidated pattern, "not a 
backward phase of development but a modern phenomenon of worldwide capitalist expansion" (Amin 1994, p. 68).

The importance of religious practices and beliefs in general as a powerful cultural instrument for defining the local society and its self-representation represents a further unavoidable consideration. This debate on religions is taking place in a border region whose cultural identity has been questioned in the recent past and continues to be so nowadays, stimulating ideological conflicts which are still far from being resolved. The different opinions about Moldovan history, language and traditional identity are strongly inter-related with the political positioning of parties, organisations and social actors, impacting also on the research topics among local historians, sociologists and political scientists (Cașu 2000; Moșneaga 2001; Serebrian 2001; Negru 2003; Cuşco and Şarov 2009; Dungaciu 2009; Gorban 2011), as well as the few recent historical monographs dedicated to the region by Western scholars (King 2000; Dima 2001; Basciani 2007). Ethnocultural and linguistic issues are also the subject of continuous speculation by various parties and organisations, with the consequences of a growing solidification of 'ethnic ideological blocks' (Vizitei 1998; Boţan 2002) and polarisation of identity tensions (Cernencu and Boțan 2009; Cazacu and Trifon 2017), which contribute to the general political instability. For Moldovan governments-who are the main promoters, together with local businessmen, of the reconstruction and financing of parishes, monasteries and theological schools-Orthodoxy represents one of the few shared pillars in the construction of the history, language and identity of "a State in which the question Who are the Moldovans? continues to concern politicians as much as scholars" (King 2000, p. 47).

Within this general scenario, the confrontation with the human rights framework represents not only a task for Moldovan political actors but also for the Orthodox Churches, as promoters of a system of shared beliefs and as social institutions. Even Orthodoxy, the heir of a centuries-old Christian dogmatic tradition founded on the universality of divine law and on the sacred nature of human being, is today increasingly pressured to acknowledge a new alternative global discourse, which demands further ethical reflection and a universally broad theology (Wolterstorff 2012; Giordan and Guglielmi 2017). As in the past, Orthodox institutions are facing renewed principles of legitimisation of their authority, consistent with different models of social cohesion and a different pattern of power. This relation is currently realised through the comparison with contents and practices strongly divergent from the pressures and adaptations faced under the Soviet agenda, with its former pattern of universality. This confirms the importance, in line with Foucault's idea of discourse as a structured network of power and knowledge, to give a contextualised framework also to the analysis of religious narratives in this bipolar local Orthodox scenario, in which human rights represents also a new juridical and institutionalised discursive regime, a new disciplinary modality of power.

Starting from these preliminary evaluations, in the final paragraph we will briefly look along which directions a context-grounded analysis of religious freedom may be moved. We will put this topic at the crossroads between the local socio-political condition anticipated here, rooted in the dynamical geography of power relations, and some variables which emerged during preparatory ethnographic observations, which indicate at different local levels the frequent reference to specific themes and a significant level of patterned responses. Finally, we will suggest an additional area needed to deepen the inquiry into the local process of conceptualisation of religious freedom, based on observing speeches and practices of Moldovan religious actors at the grassroots level.

\section{Borders, Identity and Alternative Societies. Some Preliminary Reflections on the Local Debate on Religious Freedom}

As has been pointed out thus far, the debate on religious freedom is strongly inter-related with the social role the Orthodoxy assumes in this post-Soviet context. Clear links have already been mentioned regarding the social reconfiguration processes of this region; the geopolitics in institutional relations, the management of a 'bipolar' religious hegemony by religious and political actors, the re-adaptation of Orthodox beliefs to new ideologies and social patterns, the general meaning of Orthodoxy in the 
daily life of Moldovan citizens and believers. A further important consequence of this shift lies in approaching the human rights speeches also through the framework of non-human rights institutions. The first element which emerged by observing, in this case, religious actor at the local level, stems from the particular duopolistic Moldovan panorama, which calls for a comparative inter-Orthodox approach and puts the topic of borders at the centre of the local debate on religion (Panainte 2006; Curanović 2012).

The ideological and political positioning of the two canonical Orthodox Moldovan Metropolises is not the same. On the one hand, we have the Romanian Orthodox Metropolis founded during the 1990s in connection with the declaration of independence from the Soviet Union, soon monopolised by a movement asking for, then failed, annexation to Romania. While handling their minority position at the local level, they usually mirror in their broader positioning the oscillation of the Patriarchate to which they are affiliated, with a model of collaboration between Orthodoxy and politics oscillating from a severe Romanian nationalism to attempts to enlarge symphonia to a supranational European level (Leustean 2018). While maintaining a traditionalist position, not only in the matter of gender and family-related issues but also in political theology, the BOC clergy has referred on many occasions to religious freedom as a human right, moreover criticising their contemporary condition as the heritage of the Soviet era. Although adopted in their discourse, they have also manifested awareness of how legal courts can play an active role in handling such type of social issues. A pragmatic approach toward the 'judicialization of religious freedom' (Richardson 2015), was used by the clergy not only to obtain legal recognition but also, for example, for issues related to reacquiring ownerships in the former expropriated patrimony. Looking at these claims from a political perspective, the recourse to human right discourse seems supported by a request to Europe to 'put boots on the ground' and impose its influence at its Eastern border.

On the other hand, the majoritarian Metropolis of Chisinau presents itself as 'the Church of Moldovans' but is in the meantime strictly linked to Moscow. This affiliation, which as we have seen is not just jurisdictional, is justified in the idea of a Slavic Orthodox civility, which put the universality of the 'Third Rome' as the safeguard for all the Slavic Churches. Their religious positioning towards human rights as a normative discourse has some interesting correspondence with Russian foreign policy, in which human rights discourse is often depicted as 'an ideological smokescreen' (Mälksoo 2014). According to this 'romantic-realistic interpretation' of human rights, following the definition by Morozov (2002), the human rights discourse is no more than a 'Trojan horse' offered by the West with the aim to encourage centrifugal tendencies, subvert society and hinder its internal stability. Following a perspective which we could already trace back to the tensions and disagreement displayed during the Cold War, but not uncommon also among many further western critical scholars, human rights will be interpreted "as no more than a disguise for 'real' political goals of the Western leaders" (Morozov 2002, p. 18). From the geopolitical point of view, this narrative of condemnation finds its political justification in the risk of a 'NATO-expansionism' in Eastern Europe, based on the perception that the Western military apparatus would ground their ability to impact global politics on ethical assumptions (Ratti 2009). Often referred to is the role the human rights discourse played in this sense, through the tragic effects of 'military humanitarianism', when the dissolution of Yugoslavia took place. This narrative is confirmed by many examples and local debates also among Moldovan priests and local believers. During some interviews, it has been invoked while mentioning the political and increasingly religious tensions in nearby Ukraine, but also, together with the recrudescence of Romanian nationalism, as a partial justification of the Transnistrian secession, even if often accompanied by a more disenchanted attitude. The problematic identity claim which tends to equate Moldovan citizenship and Orthodox belief has thus some instrumental assonance with the critics of human rights discourse as an expression of the post-Cold War 'moral imperialism' (Hernández-Truyol 2002). At the same time, in comparison with those related to the Romanian Patriarchate, the positioning of these priests and bishops towards the Soviet era are more usually multi-faceted and contradictory, condemning atheistic cultural policies while displaying during interviews even nostalgic notes. Associated with the more 
common point of view of religious actors, the concerns about human rights—and religious freedom among them-would be often included in the process of securitisation of identity. The oppositions to selected elements of the human rights discourse would reinforce narratives centred on the borders between 'us' and 'them': Orthodox values will be called upon as the alternative cultural tradition on which the unity of the Orthodox community is built. Following this positioning 'some human rights can be considered as heresy', as affirmed by the Patriarch Kirill (Dolgov 2016).

In summary, this short review has shown how this ecclesiological duplicity encompasses not only the role of Churches as regional actors, but also their influence as geopolitical soft-power agents, mirroring and building political borders at the local level too. The Orthodox discourses about identity, like the political one, are oscillating between the Romanian model of European integration and the neo-traditionalist Russian one that, as stated by Burgess, among others, "while eager to achieve a Western standard of living, did not now think of themselves as mere junior Europeans" (Burgess 2017, p. 19). If the Moldovan 'Western proposal' does not refuse a strong nationalistic identification based on Orthodoxy, promoting Romanianism as the majoritarian and dominant identity of this border multi-ethnic region, 'Slavic' Moldovan believers receive from Moscow a call for loyalty in sharing common alternative civilizational values, deeply rooted in and safeguarded by Christian Orthodoxy (Suslov 2015; Munteanu 2015). Not surprisingly, even in very recent times, different political exponents have stressed their trust in MOC for definitely overcoming the tensions with Transnistria. Along with discrepancies here marked, a very relevant commonality between both institutions lies in the fact that both define themselves as national Churches, encouraging an extensive use of identity narratives. During the last three decades, Orthodoxy as a whole has been engaged in the reconstruction-if not invention-of a post-Soviet Moldovan national tradition, which has been mainly founded on religion. This religious tradition is a rediscovery made by a young clergy, partly still in the course of institutionalisation, and by believers who had for decades only a private religiosity, confined to domestic rituals and few festivities. After decades of semi-interrupted transmission, a tradition known for its theological conservatism has also "largely been reinvented in the process of reconstructing the Church" (Rousselet 2013, p. 11), in dialogue with the questions raised by the current local and global social dynamics. National identity represents a persistent topic produced and reproduced by both the Metropolises and strongly related, as already observed, to the issue of religious freedom. For religious actors from both Orthodox institutions, Orthodoxy represents and protects the traditional culture, with a clear affirmation that the harmony in the Christian community is more important than religious freedom. While condemning the crumbling of moral reference and the fragility of the new social assets, usually mentioning political corruption too, the Orthodox doctrinal proposals would be based on the loyalty to a shared traditional memory, based on the religion of Fathers and addressed not only to religious practitioners but also to an entire Orthodox nation, with its people in symphonic communion with the body of the Church (Hilarion 2010; Stăniloae 2001).

The claims of cultural specificity in these identity narratives affect the approach toward human rights in general, enriching the complexity of the previous geopolitical interpretation. The internal debate on Moldovan identity opens a broader understanding also of the 'politics of human rights', which need to be recognised and analysed in the capacity to influence and shape, in the same way as religions do, individual attitudes, cultural patterns and social configurations. While the human rights 'as ideology' is often criticised, their contents are debated on both theological and practical terms, usually not framed through the same lexicon associated with the institutional human rights discourse. The legal separation between Church and State is, for example, unanimously accepted by priests when intended at the legal level, also because it is considered, as we have already seen among political parties, a proper answer. In the same way, the individual freedom of conscience rarely has negative connotations, despite for example the clear historical declaration of an interviewed local bishop, who stated that 'freedom did not bring many good things'. Attributing the role of moral-source for collectivity to Orthodoxy is nonetheless a consolidated and widespread opinion. In striking contradiction with the Soviet past, the theological positions taken by Churches enter the 
public sphere and regularly have influence on social issues and law-making processes, with Orthodox experts consulted especially while dealing with issues connected with the moral dimension of social life, in education, health, gender and family.

The strong emphasis placed on traditional identity is strictly related to the idea of public morality and social security. As a consequence, despite few official documents or extemporary declarations-devoted in most cases to preserve, through adaptations, a conservative political theology made compatible with liberal paradigms-the religious debate on religious freedom is mainly realised in dialogue with other topics. It would be related for example to the attitude towards religious minorities, to the protection of cultural heritage and the education of children, or to disputes on how to deal with the dimension of individual freedom notwithstanding a Christian understanding of the society (Kirill 2011). Among some religious actors the positions assumed on these topics adhere to a striking conservative agenda. For example, the previously mentioned Bishop of Balti is well known as committed to fighting the implementation of LGBTQ rights. During the debate on the adoption of a law for equality-while the Synod of the MOC was officially defining the law as an attack on traditions and Christian public morality (Moldovan Orthodox Church 2013)- -he even complained that this law 'would give for gays the possibility to work in a blood transfusion centre'.

In this attempt to contextualise the construct of religious freedom, the topic of social security represents a third thematic field which clearly emerged during this preparatory, ongoing enquiry. In this regard we would underline a final relevant issue, partly omitted until now. The growth of Orthodoxy in Moldova is connected, above all, to its role in the reconstruction of a social order, through the centrality of its rituals in the empowerment of individual agency, through a widespread sense of belonging in a community of believers, through the effectiveness the parishes have in the reconstruction of a post-Soviet society. Notwithstanding the vagueness and uncertainty of the concrete separation between religious and state actors, the social roles Orthodoxy assumes are primarily connected with the inefficacy of political institutions, in dialectic with the absence of politics. The role and the efficacy of Orthodoxy in the Moldovan context mostly lies in spite of and beyond the State, operating in spaces left behind by the formal political control of the territory. Orthodox parishes create new spaces of adaptation especially where citizens consider state governance as not appropriate or ineffective, or where political institutions deliberately have not any will of regulation. Usually, local religious actors share with believers the political disillusionment and the retreat into informal practices which is widespread among Moldovan citizens.

An anthropological observation of the Orthodox communities, concentrated at grassroots level, shows how those 'religious answers' are usually considered to be far beyond the legal discourse. After the end of the Soviet Union, as long as the influence of human rights was emerging with new strength-as principles, institutional structures and praxis-Moldovans were experiencing the consequences of a drastic transition toward the global market economy, combined with a deep lightening of political control on economy and society. Despite being perceived as instruments of potential empowerment, human rights standards have been considered part of the multi-level administrative space created by the interacting structures of authority, market forces included, which during the 1990s led to the dramatic crumbling of all societal structures. Human rights, and religious freedom among them, would be thus connected with the widespread critical attitude towards politics, which goes from ironic indifference to antagonism. As some interviews seem to show, one consequence of this is that religious freedom, when perceived as counteracting religious identity, is also considered as undermining this fragile attempt to create new forms of political organisation and social belonging.

For many Moldovans, their country is still characterised by economic fragility, social fragmentation and a generic sense of insecurity. The local role of Orthodoxy, and the religious phenomena in general, seems to offer believers the opportunity of responding to this scenario, going not only beyond the space of the sanctuary, where prayers and collective rituals create spaces of mutual recognition and suggest a renewed embodied sense of security, but also beyond the geopolitical and institutional mutual instrumentalism that are carried out between religious and governmental players. Especially at the 
level of local community, and despite its liturgy-centred theology, the Orthodox Churches participate in those informal spaces and practices that became so essential in the post-Soviet phenomena of replacing, renegotiating, and reshaping the local governance (Polese 2016). Priests become not only the pillar of a shared generic sense of religious and traditional belonging, but protagonists of a context in which the distinction between citizen and believer is blurred. Through parishes, informality also enters formal social institutions. For example, in the economic and symbolic network created behind the altars, the new protagonists of the social life of the country, starting with local businessmen, are blessed as founders of the temple and supporters of religious activities, and therefore recognised as legitimate producers and reproducers of society at large.

We should mention that this 'religious answer', even if deeply rooted in a strong and diffused sense of religiosity, is far from being unanimously considered effective and ethical. Although many respondents signaled how religion is important for them, the social authority of priests is not uncontested even among the villages near the former kolkhozy, where usually the parishes represent today the only social space dedicated to collectivity. In some cases, Orthodox institutions can appear to be both the safeguards of the social order and at the same time be considered corrupt and profit-oriented organisations, addressed with the same distrust we mentioned regarding political institutions. Despite this, the current transfiguration of politics that Orthodox communities are contributing to realise opens the most relevant discrepancy between the institutional human rights discourse and its social perception. The objective virtuality of religious freedom as law seems to be far from the inter-subjective reality of rights, a dimension in which the right to religious freedom might appear insubstantial, or even in competition with the religious attempt to answer matters of social insecurity. The widespread feeling of lacking references and control over social life has, in this sense, a huge impact both on the Moldovan social scenario and on the local conceptualisation of religious freedom. While religious freedom as a human right is an expression of a discourse founded on the growing co-extensivity of predicates of humanity with those of citizenship, which Balibar (2004) properly placed at the foundation of political modernity, Moldovan Orthodox communities became the protagonists of a widespread micro-societal process of adaptation to the crisis of modern citizenship. They develop practices and discourses which bypass the paradigmatic proceduralism of laws as well as the disembodied neutrality of rights, reconnecting belonging with believing.

Funding: This research received no external funding.

Conflicts of Interest: The author declares no conflict of interest.

\section{References}

American Anthropological Association. 1947. Statement on Human Rights. American Anthropologist 49: 539-43. [CrossRef]

American Anthropological Association. 1999. 1999 Statement on Human Rights. Available online: www.humanrights. americananthro.org (accessed on 1 March 2019).

Afkhami, Mahnaz. 2000. Faith and Freedom: Women's Human Rights in the Muslim World. London: Tauris Publ. Amin, Samir. 1994. Re-Reading the Postwar Period: An Intellectual Itinerary. New York: Monthly Review Press.

Balan, Elena. 2009. Socializarea politică: Abordări conceptuale. Revista de filozofie, sociologie şi ştiinţe politice 3: 65-72.

Balibar, Étienne. 2004. Is a philosophy of human civic rights possible? New reflections on equaliberty. South Atlantic Quarterly 103: 311-22. [CrossRef]

Banchoff, Thomas F., and Robert Wuthnow, eds. 2011. Religion and the Global Politics of Human Rights. New York: Oxford U.P.

Barnett, Michael N., and Martha Finnemore. 2004. Rules for the World: International Organizations in Global Politics. Ithaca: Cornell University Press.

Basciani, Alberto. 2007. La difficile unione la Bessarabia e la grande Romania, 1918-1940. Roma: Aracne.

Berger, Peter L., ed. 1999. The Desecularization of the World: Resurgent Religion and World Politics. Washington, DC: Ethics and Public Policy Center. 
Bobick, Michael. 2011. Profits of disorder: Images of the Transnistrian Moldovan Republic. Global Crime. 12: 239-65. [CrossRef]

Boţan, Igor. 2002. Armonizarea relaţiilor interetnice—Sfidări şi oportunităţi. Chişinău: IPP.

Breskaya, Olga, Giuseppe Giordan, and James T. Richardson. 2018. Human Rights and Religion: A Sociological Perspective. Journal for the Scientific Study of Religion 57: 1-13. [CrossRef]

Burgess, John P. 2017. Holy Rus': The Rebirth of Orthodoxy in the New Russia. New Haven: Yale U.P.

Casanova, José. 1994. Public Religions in the Modern World. Chicago: Chicago U.P.

Cașu, Igor. 2000. Politica națională în Moldova Sovietică 1944-1989. Chișinău: Cartdidact.

Catana, Vitali. 2004. The Legal Status of Churches in the Republic of Moldova-Provisions and Practice. In Legal Positions of Churches and Religious Communities in South-Eastern Europe. Edited by Devetak Silvio, Kalčina Liana and Polzer Miroslav. Maribor: Iscomet.

Cazacu, Matei, and Nicolas Trifon. 2017. Un État en quête de nation: La République de Moldavie. Paris: Nonlieu.

Cernencu, Mihai, and Igor Botan. 2009. The Evolution of the Multiparty System in Moldova. Chisinău: ADEPT.

Ciorba, Veaceslav. 2011. Biserica Orthodoxă din Basarabia şi Transnistria (1940-2010). Chişinău: Pontos.

Cojocaru, Natalia. 2006. Nationalism and Identity in Transnistria. The European Journal of Social Science Research 19: 261-72. [CrossRef]

Cox, Harvey G. 1994. Fire from Heaven Pentecostalism, Spitituality and the Reshaping of Religion in the Twenty-First Century. London: Cassell.

Curanović, Alicja. 2012. Religious Factor in Russia's Foreign Policy. New York: Routledge.

Cuşco, Andrei, and Igor Şarov. 2009. Identitate, memorie şi discurs istoric în Moldova postsovietică: O abordare critică. In Istoriografie şi politică în estul şi vestul spaţiului românesc. Edited by Svetlana Suveică, Ion Eremia, Sergiu Matveev and Sorin Şipoş. Chişinău: Oradea U.P., pp. 72-87.

Dailey, Erika, Jeri Laber, and Lois Whitman. 1993. Human Rights in Moldova: The Turbulent Dniester. New York: Helsinki Watch.

De Martino, Ernesto. 1977. La fine del mondo. Torino: Einaudi.

de Sousa Santos, Boaventura. 2015. If God Were a Human Rights Activist. Stanford: Stanford U.P.

Dima, Nicholas. 2001. Moldova and the Transdnestr Republic. New York: Columbia U.P.

Dolgov, Anna. 2016. Russia's Patriarch Kirill: Some Human Rights Are 'Heresy'. Moscow Times. March 21. Available online: www.old.themoscowtimes.com (accessed on 1 March 2019).

Dungaciu, Dan. 2009. Cine suntem noi? Cronici de la Est de Vest. Chișinău: Cartier.

Dupouy, Hervé. 2001. 'La Moldavie'. In Les états postsovietiques. Edited by Radvanyi Jean. Paris: Armand Colin, pp. 56-73.

Durham, W. Cole. 2012. Patterns of Religion State Relations. In Religion and Human Rights: An Introduction. Edited by John Witte and M. Christian Green. Oxford: Oxford U.P., pp. 360-78.

Ferrari, Silvio. 2005. Lo spirito dei diritti religiosi: Ebraismo, cristianesimo e islam a confronto. Bologna: Il mulino.

Finke, Roger. 2013. Origins and consequences of religious freedom: A global overview. Sociology of Religion 74: 297-313. [CrossRef]

Fokas, Effie. 2015. Directions in religious pluralism in Europe: Mobilizations in the shadow of European Court of Human Rights religious freedom jurisprudence. Oxford Journal of Law and Religion 4: 54-74. [CrossRef]

Fox, Jonathan. 2008. A World Survey of Religion and the State. New York: Cambridge U.P.

Freeman, Michael. 2002. Human Rights: An Interdisciplinary Approach. Cambridge: Polity.

Fukuyama, Francis. 1992. The End of History and the Last Man. London: Hamish Hamilton.

Giordan, Giuseppe, and Marco Guglielmi. 2017. Ortodossia cristiana, modernità e la questione dei diritti umani. Prospettive teoriche. Religioni e società 32: 41-49.

Goodale, Marc. 2009. Surrendering to Utopia: An Anthropology of Human Rights. Stanford: CA Stanford U.P.

Gorban, Anna. 2011. Ethnic and Socio-Cultural Aspects of Political Culture in Moldova. In Ethnicity, Confession and Intercultural Dialogue at the European Union's East Border. Edited by Mircea Brie, Ioan Horga and Sorin Şipoş. Debrecen and Oradea: Eurolimes, pp. 133-51.

Grim, Brian J., and Roger Finke. 2006. International religious indexes: Governmental regulation, government favoritism, and social regulation of religion. Interdisciplinary Journal of Research on Religion 2: 1-38.

Habermas, Jürgen. 1996. Between Facts and Norms: Contributions to a Discourse Theory of Law and Democracy. Cambridge: Polity Press.

Hernández-Truyol, Berta Esperanza, ed. 2002. Moral Imperialism: A Critical Antology. New York: New York U.P. 
Hilarion, Metropolitan of of Volokolamsk [Alfeyev, Grigoriy Valerievich]. 2010. Patriarkh Kirill: Zhizn' i Mirosozertsanie. Moscow: Eksmo.

Islamic Human Rights Commission. 2003. Briefing: Moldova's Unofficial Muslims. Available online: www.ihrc. org.uk (accessed on 1 March 2019).

Jenkins, Willis J. 2008. Ecologies of Grace: Environmental Ethics and Christian Theology. Oxford: Oxford U.P.

Joas, Hans. 2013. The Sacredness of the Person: A New Genealogy of Human Rights. Washington, DC: Georgetown U.P. Kepel, Gilles. 1992. La revanche de Dieu: Chrétiens, juifs et musulmans à la reconquête du monde. Paris: Le Seuil.

King, Charles. 2000. The Moldovans: Romania, Russia, and the Politics of Culture. Stanford: Hoover U.P.

Kirill, Patriarch of Moscow [Gundyayev, Vladimir M]. 2011. Libertatea și responsabilitatea: În căutarea armoniei. Drepturile omului și demnitatea personal. Chișinău: Tipografia Centrala.

Langlaude, Sylvie. 2007. The Right of the Child to Religious Freedom in International Law. Boston: Martinus Nijhoff.

Leustean, Lucian N. 2018. The politics of Orthodox churches in the European Union. International Journal for the Study of the Christian Church 18: 146-57. [CrossRef]

Livizeanu, Irina. 1995. Culturâ si nationalism în Romania Mare. Bucarest: Humanitas.

Luhmann, Niklas. 1965. Grundrechte als Institution: Ein Beitrag zur politischen Soziologie. Berlin: Duncker und Humblot.

Madsen, Mikael R., and Gert Verschraegen, eds. 2013. Making Human Rights Intelligible. Towards a Sociology of Human Rights. Oxford: Portland: Hart.

Mälksoo, Lauri. 2014. Russia and European Human-Rights Law. The Rise of the Civilizational Argument. Leiden: Brill Nijhoff.

Messer, Ellen. 1993. Anthropology and Human Rights. Annual Review of Anthropology 22: 221-49. [CrossRef]

Moldovan Institute for Public Policy. 2017. Barometrul de Opinie Publica-April 2017. Available online: www.statistica.md (accessed on 1 March 2019).

Moldovan Orthodox Church. 2013. Adresarea Sinodului Bisericii Ortodoxe din Moldova către autoritățile de vârf ale țării, pentru modificarea Legii anti-discriminare. Available online: www.mitropolia.md (accessed on 1 March 2019).

Moldovan Orthodox Church. 2018. Calendar Bisericesc Ortodox. Chişinău: Consiliul Editorial al Bisericii Ortodoxe din Moldova.

Morini, Enrico. 1996. La Chiesa Ortodossa. Storia, disciplina, culto. Bologna: EDS.

Morozov, Viatcheslav. 2002. Human Rights and Foreign Policy Discourse in Today's Russia: Romantic Realism and Securitisation of Identity. Cooperation and Conflict 37: 409-29. [CrossRef]

Morsink, Johannes. 1999. The Universal Declaration of Human Rights: Origins, Drafting, and Intent. Philadelphia: Pennsylvania U.P.

Moșneaga, Valeriu. 2001. Moldova între Est şi Vest: Identitatea naţională şi orientarea europeană. Chişinău: USM.

Munteanu, Victor. 2015. Behind the Curtain: The relationship between the Moldovan state and Church. In Traditional Religion and Political Power. Examining the Role of the Church in Georgia, Armenia, Ukraine and Moldova. Edited by Adam Hug. London: The Foreign Policy Centre.

Nash, Kate. 2015. The Political Sociology of Human Rights. Cambridge: Cambridge U.P.

National Bureau of Statistics—Republic of Moldova. 2014. Recensământului Populației și Locuințelor. Available online: www.statistica.md (accessed on 1 March 2019).

National Bureau of Statistics-Republic of Moldova. 2018. Statistical Reports Database. Available online: www.statistica.md (accessed on 1 March 2019).

Negru, Elena. 2003. Politica etnoculturala în RASS Moldoveneasca (1924-1940). Chisinàu: Prut International.

Negură, Petru. 2015. Republica Moldova la un sfert de veac de tranziţie: Între un comunism ratat şi un capitalism ne început? In Republica Moldova la 25 de ani. O privire de sinteză. Edited by Petru Negură, Vasile Ernu and Vitalie Sprînceană. Chişinău: Cartier, pp. 19-52.

Palombella, Gianluigi. 2006. Dopo la certezza: Il diritto in equilibrio tra giustizia e democrazia. Bari: Dedalo.

Panainte, Sergiu. 2006. Secularism in Republic of Moldova-Politics of Religion or Religious Politics: Where Do We Draw the Boundaries? Romanian Journal of Political Science 6: 89-100.

Polese, Abel. 2016. Limits of a Post-Soviet State. Stuttgart: Ibidem press.

Popescu, Tiberiu C. 2004. L'Église moldave entre les patriarcats de Moscou, Constantinople et Bucarest. Revue d'études comparatives Est-Ouest 35: 191-98. [CrossRef]

Price, Daniel. 2002. Islam and human rights: A case of deceptive first appearances. Journal for the Scientific Study of Religion 41: 213-25. [CrossRef] 
Ratti, Luca. 2009. Back to the Future? International Relations Theory and NATO-Russia Relations since the End of the Cold War. International Journal 64: 399-422. [CrossRef]

Richardson, James T. 2004. Regulating Religion: Case Studies from Around the Globe. New York: Kluwer.

Richardson, James T. 2006. The sociology of religious freedom: A structural and socio-legal analysis. Sociology of Religion 67: 271-94. [CrossRef]

Richardson, James T. 2015. Managing religion and the judicialization of religious freedom. Journal for the Scientific Study of Religion 54: 1-19. [CrossRef]

Rousselet, Kathy. 2013. L'autorité religieuse en contexte post-soviétique. Regard sur le fonctionnement des paroisses russes orthodoxes. Archives de sciences sociales des religions 162: 15-36. [CrossRef]

Rutland, Peter. 2013. Neoliberalism and the Russian Transition. Review of International Political Economy 20: 332-62. [CrossRef]

Sarkissian, Ani. 2015. The Varieties of Religious Repression. Why Governments Restrict Religion. Oxford: Oxford U.P. Serebrian, Oleg. 2001. Basarabia: Geopolitica unei identităţi în derive. In Politosfera. Chişinău: Cartier, pp. $134-44$. Somers, Margaret R., and Christopher N. J. Roberts. 2008. Toward a new sociology of rights: A genealogy of 'buried bodies' of citizenship and human rights. Annual Review of Law and Social Science 4: 385-425. [CrossRef]

Stăniloae, Dumitru. 2001. Ortodoxie și nationalism. Bucarest: Supergraph.

Suslov, Mikhail D. 2015. Holy Ru': The Geopolitical Imagination in the Contemporary ROC. Russian Social Science Review 56: 43-62. [CrossRef]

Suveică, Svetlana, and Vitalie Sprînceană. 2015. Perspectives on Human Rights and Religion in Moldova. In Religion and Human Rights. Edited by Hans-Georg Ziebertz and Gordan Crpic. Cham: Springer, pp. 103-12.

Thomas, Scott. 2005. The Global Resurgence of Religion and the Transformation of International Relations. The Struggle for the Soul of the Twenty-First Century. New York: Palgrave Macmillan.

Thornberry, Patrick. 2002. Indigenous Peoples and Human Rights. Manchester: Manchester U.P.

Tihonov, Ludmila. 2013. KGBul sovietic şi Biserica ortodoxă din RSSM. In Basarabia ortodoxa din interfluviul Pruto-Nistrean (1813-2013). Edited by Octavian Moşin and Ion Gumenâi. Chişinău: Cuvântul ABC, pp. 186-96.

Todorov, Tzvetan. 1992. Nous et les autres: La réflexion française sur la diversité humaine. Paris: Seuil.

Turner, Brian S. 1993. Outline of a theory of human rights. Sociology 27: 489-512. [CrossRef]

Turner, Terence. 1997. Human rights, human difference: Anthropology's contribution to an emancipatory cultural politics. Journal of Anthropological Research 53: 273-91. [CrossRef]

UN Human Rights Council. 2012. Report of the Special Rapporteur on Freedom of Religion or Belief-Heiner Bielefeldt. January 27 A/HRC/19/60/Add.2. Available online: www.ohchr.org (accessed on 1 March 2019).

United States Department of State-Bureau of Democracy, Human Rights and Labor. 2017. International Religious Freedom Report-Moldova. Available online: www.state.gov (accessed on 1 March 2019).

Van der Ven, Johannes A., and Hans-Georg Ziebertz, eds. 2012. Tensions within and between Religions and Human Rights. Leiden and Boston: Brill.

Van der Vyver, Johan David, and John Witte, eds. 1996. Religious and Human Rights in Global Perspective: Legal Perspectives. The Hague: Martinus Nijhoff.

Ventura, Marco. 2015. Human rights within religions. In Routledge Handbook of Law and Religion. Edited by Ferrari Silvio. New York: Routledge, pp. 161-78.

Vizitei, Nikolai. 1998. Ideologo mirovozzrencheskaja situacija v Moldove: Istoki, osnovnye protivorechija, vozmozhnye transformacii. In Moldova, România, Ucraina-bună vecinătate şi colaborare regional. Edited by Valeriu Moşneaga. Chişinău: Perspectiva, pp. 225-31.

Voicu, Ovidiu, Jennifer Cash, and Victoria Cojocariu. 2017. Biserică şi Stat în Republica Moldova. Chişinău: Soros Foundation-Moldova/Public Innovation Centre.

Witte, John, and M. Christian Green. 2012. Religion and Human Rights: An Introduction. Oxford: Oxford U.P.

Wolterstorff, Nicholas P. 2012. Christianity and human rights. In Religion and Human Rights: An Introduction. Edited by John Witte and M. Christian Green. Oxford: Oxford U.P., pp. 42-55.

Zuber, Valentine. 2017. La liberté religieuse: Droits de l'Homme et religions dans l'action extérieure de la France. Paris: Van Dieren. 